\title{
Response of Growth and Yield of Eggplants (Solanum melongena L.) to Organic Mulches and Nitrogen Fertilization Levels During Late Summer Season
}

\section{E.M.H. El-Semellawy and H.M. El-Koumy}

Vegetable Department, Horticulture Research Institute, Agriculture Research Centre, Cairo, Egypt.

WO FIELD experiments were conducted with eggplant
(cv. Sawad El laiel $\mathrm{F}_{1}$, supplied by Samtrade company) during
the successive summer seasons of 2013 and 2014 at a private farm,
Kafr El-sheikh Governorate, Egypt to investigate the effect of nitrogen
rates ( 50,100 and $150 \mathrm{~kg} / \mathrm{fed}$.), organic mulch (Rice straw, wheat
straw and dry grass as well as the bare soil as a control), and their
interaction on vegetative growth parameters, yield and fruit quality of
eggplants. The obtained results showed that increasing $\mathrm{N}$ applied rate
was accompanied with significant increases in vegetative growth
characterstics (plant height ( $\mathrm{cm}$ ), number of branches and leaves, leaf
area (cm ${ }^{2}$ ), plant fresh weight (g), both early and total yield and fruit
quality (average fruit weight (g) and both length and width of
fruit (cm) by increasing $\mathrm{N}$ rates up to $150 \mathrm{~kg} / \mathrm{fed}$ On the other hand,
nitrogen use efficiency was decreased with increment of $\mathrm{N}$ rate.
Organic mulch treatments had a positive effect on vegetative growth
parameters, total yield, fruit quality and nitrogen use efficiency
compared with bare soil which had the highest early yield. The best
results of aforementioned parameters were recorded by using different
types of organic mulch and plants fertilized with $100 \mathrm{~kg} / \mathrm{fed} \mathrm{of}$
Nitrogen.

Keywords: Eggplant, Nitrogen rate, Organic mulch, Nitrogen use efficiency.

Eggplant (Solanum Melongena, L.) is one of the most important and popular vegetable crops in Egypt and is considered as a national diet in many other tropical and sub - tropical countries. Eggplant fruits contain a considerable amount of carbohydrates, proteins and some minerals (El-Nemr et al., 2012).

Plant nutrition is one of the most important factors that increase plant production, nitrogen is one of the major elements for plant growth and development that has an important role in plant nutrition and therefore is the yield - limiting factor for plant growth in many areas especially in low organic soil (Najafva Direkvandi et al., 2008). Many investigators reported that maximum yield of eggplant can be achieved with the application of $\mathrm{N}$ fertilizer at rate ranging from 20-80 kg/ha. (Moraditochaee et al., 2011, Bozorgi, 2012 and 
Azarpour et al., 2012). Aminifard et al. (2010) showed that the best yield of eggplant was resulted with $100 \mathrm{~kg} \mathrm{~N}$ per hectar. Also, many studies indicated that growth and yield of eggplant gradually increased with increasing the levels of nitrogen until $120 \mathrm{~kg} / \mathrm{ha}$.(Feleafel, 2005, Amiri et al., 2012 and Aman \& Rab, 2013) and until $150 \mathrm{~kg} / \mathrm{ha}$. with (Lima et al., 2014).

Kostadinov and Kostadinova (2014) reported that the yield of eggplant was significantly increased with increasing rates of $\mathrm{N}$ to $240 \mathrm{~kg} / \mathrm{ha}$. Also, they added that the agronomic efficiency of nitrogen was strongly and positively related to the physiological and recovery efficiency as well as to the nitrogen harvest index. Feleafel and Mirdad (2013) achieved the highest yield of eggplant by using the nitrogen rate $250 \mathrm{~kg} / \mathrm{ha}$. Halitligil et al. (2002) studied three different $\mathrm{N}$ levels, 200,400 and $600 \mathrm{~kg} / \mathrm{ha}$. in drip irrigation for 50,100 and $150 \mathrm{mg} \mathrm{N} / \mathrm{L}$. treatments, and they found that the highest yield of eggplant was achieved with treatment of $150 \mathrm{mg} \mathrm{N} / \mathrm{L}$. (400 kg N/ha.). Also, they concluded that the nitrogen use efficiency (NUE) was significantly increased by applying the nitrogen fertilizer rate.

Surface mulch either by synthetic plastic films or natural organic waste material is recently being used to protect plants from root borne diseases and for water conservation. organic mulches including sawdust, dry grass, lawn clippings, maize cobs, rice and wheat straw, water hyacinth etc., have been very effective for vegetative growth and yield through improving soil water content. soil temperature and adding some of the organic nitrogen and other minerals to improve soil nutrient status. Increase plant growth and yield, moderation of soil temperature, conservation of water, reduction of nutrient loss by leaching and control of weeds are some advantages of mulching in growing eggplant or other commercial vegetable crop (Pessarakli and Dris, 2004).

Many investigators indicated that, organic mulch has a favorable effect on growth, yield and quality of vegetable crops (Carter \& Johnson, 1988, El- Sawy, 1993, Abdul-Baki and Stommel, 1996, El-Aidy et al., 2000, Thakur et al., 2000, Thakur et al., 2002, Rodriguez, 2007, Saeed \& Ahmad, 2009, Sathappan et al., 2012 and Pirbonch et al., 2012).

Shaikh and Fouda (2008) reported that the maximum soil temperature about $3^{0} \mathrm{C}$ with using wheat straw mulch and the yield of cucumber plants was increased by $67 \%$ compared with the plants growing with bare soil. Law et al. (2006) cleared that application organic mulches, straw, compost and wood chips, significantly increased the pepper yield compared with the bare soil.

Thus, the objective of the present work was to study the effect of nitrogen rates and organic mulches on growth, yield and the fruit quality of eggplant. 


\section{Materials and Methods}

This study was carried out at a private farm in El-Shamarka village, Kafrelsheikh Governorate, Egypt during the late summer seasons of 2013 and 2014. The experiments were conducted on eggplant, cv. Sawad El-Laiel $F_{1}$ hybrid (supplied by Samtrade company).

The soil texture was clay, physical and chemical analysis were determined according to Jackson \& Strelec (1967) and Black (1965), the data presented in Table 1 .

TABLE 1. Physical and chemical analysis of soil before conducting the experiment during 2013 and 2014 seasons.

\begin{tabular}{|l|c|c|}
\hline \multicolumn{1}{|c|}{ Soil properties } & \multicolumn{2}{|c|}{ Seasons } \\
\cline { 2 - 3 } & $\mathbf{2 0 1 3}$ & $\mathbf{2 0 1 4}$ \\
\hline Sand \% & 21.45 & 22.47 \\
Silt \% & 29.60 & 30.17 \\
Clay \% & 48.95 & 47.36 \\
Soil type & clay & clay \\
\hline $\mathrm{pH}$ & 8.57 & 8.41 \\
\hline Ec/ 25 $\mathrm{C}(\mathrm{mmhos} / \mathrm{cm})$ & 3.7 & 3.4 \\
\hline Available N (mg/100g soil) & 32.70 & 40.53 \\
Available P (mg/100g soil) & 10.71 & 9.02 \\
Available K (mg/100g soil) & 104.06 & 103.50 \\
\hline
\end{tabular}

The seedlings of eggplant were transplanted on $10^{\text {th }}$ and $7^{\text {th }}$ of May in the first and second seasons, respectively, on both sides of each ridge $(1.6 \mathrm{~m}$ width and $6 \mathrm{~m}$ long) at a space of $0.5 \mathrm{~m}$ between plants. Each plot consisted of two ridges having an area of $19.2 \mathrm{~m}^{2}$, a guard row was left between each two adjacent plots. Fertilization of the experiments were $300 \mathrm{~kg} / \mathrm{fed}$. Calcium super phosphate $\left(15 \% \mathrm{p}_{2} \mathrm{O}_{5}\right) 200 \mathrm{~kg} / \mathrm{fed}$ was added during soil preparation. Potassium sulphate $\left(50 \% \quad \mathrm{~K}_{2} \mathrm{O}\right)$ were divided into three equal parts added with the first irrigation, one month after transplanting and two months later. Furrow irrigation system was used and the control of weeds, insects and diseases was carried out when it was necessary.

Treatments used and experimental design, Nitrogen rates, i.e., 50, 100 and $150 \mathrm{~kg} / \mathrm{fed}$. were used as ammonium nitrate, divided into three equal parts added with first irrigation, with the first flowering and after the second picking date. The mulch treatments were rice straw, wheat straw, dry grass and bare soil as control. The organic mulches were spread on the soil (about $85 \%$ from soil surface was covered) between the rows and around plants after 5 days from transplanting, the thickness of organic mulches layer was about $5 \mathrm{~cm}$. A Splitplot design with three replicates was used. The $\mathrm{N}$ rates were randomly arranged in the main plots while, the mulch treatments were randomly distributed in the sub- plots. 
In each experimental unit the first ridge was allocated to measuring the vegetative growth characters, at 110 days after transplanting, i.e. plant height $(\mathrm{cm})$, number of branches, number of leaves, leaf area $\left(\mathrm{cm}^{2}\right)$ and plant fresh weight $(\mathrm{g})$, the second one was regard to determine the yield and its components, i.e, the early yield (fruits weight of the first four pickings in plot and converted into ton/fed.), the total yield (total fruits weight of all pickings / season (15 pickings) for plot and converted into ton/fed.) and nitrogen use efficiency (NUE) according to the equation of: NUE = Total fruits yield (ton / fed.) / $\mathrm{N}$ application rate $(\mathrm{kg} / \mathrm{fed})$ of each treatment. Harvesting started at about 45 days after transplanting and continued until the end of experiments in October in both seasons.

Five fruit from each sub- plot were taken randomly to determine the fruit characteristics, average fruit weight $(\mathrm{g})$, fruit length and fruit width $(\mathrm{cm})$. Soil temperature was recorded at $5 \mathrm{~cm}$ depth under the soil surface at 3- day intervals during the growing season and recorded twice daily at 7 a.m. (minimum) and 14 p.m. (maximum) by using the thermometers. Average soil temperatures for mulching treatments were calculated as monthly average (Table 2). Data were tested by analysis of variance according to Little and Hills (1972). Duncan's multiple range test was used for comparison among treatments means.

TABLE 2. Maximum and minimum monthly soil temperature $\left({ }^{\circ} \mathrm{C}\right)$ as affected by organic mulch during the two growing seasons of 2013 and 2014.

\begin{tabular}{|l|c|c|c|c|c|c|c|c|}
\hline \multirow{3}{*}{ Month } & \multicolumn{9}{|c|}{ 2013 Season } \\
\cline { 2 - 9 } & Bare soil & \multicolumn{2}{|c|}{ Rice straw } & \multicolumn{2}{c|}{ Wheat straw } & \multicolumn{1}{c|}{ Dry grass } \\
\cline { 2 - 9 } & Max. & Min. & Max. & Min. & Max. & Min. & Max. & Min. \\
\hline June & 31.5 & 24.7 & 27.5 & 26.0 & 28.3 & 26.4 & 28.1 & 26.4 \\
\hline July & 30.5 & 25.7 & 27.2 & 26.4 & 27.2 & 26.3 & 27.4 & 27.7 \\
\hline August & 32.2 & 25.6 & 28.2 & 26.2 & 28.9 & 26.6 & 26.5 & 28.7 \\
\hline September & 29.3 & 24.3 & 26.3 & 25.1 & 26.5 & 25.4 & 26.4 & 25.4 \\
\hline \multicolumn{8}{|c|}{ 2014 Season } \\
\hline June & 35.9 & 23.0 & 30.5 & 27.9 & 31.4 & 28.4 & 31.6 & 28.7 \\
\hline July & 34.1 & 26.9 & 30.0 & 28.0 & 31.3 & 28.4 & 31.1 & 27.9 \\
\hline August & 33.2 & 25.2 & 31.0 & 29.0 & 30.5 & 28.6 & 30.3 & 28.4 \\
\hline September & 30.5 & 23.8 & 27.7 & 25.3 & 27.3 & 25.2 & 27.8 & 22.3 \\
\hline
\end{tabular}

\section{Results and Discussion}

\section{Vegetative Growth}

Data in Table 3 showed that vegetative growth parameters, i.e. plant height, number of branches, number of leaves, plant fresh weight and leaf area were significantly increased gradually as affected by nitrogen application rates from 50 until $150 \mathrm{~kg} \mathrm{~N}$ per feddan in both seasons. The positive effect of $\mathrm{N}$ on vegetative growth parameters of eggplant may be explained on the basis of $\mathrm{N}$ plays a major role in protein and nucleic acids synthesis and protoplasm formation as well as stimulates the meristamic activity for producing more

Egypt. J. Hort. Vol. 42, No. 2 (2015) 
tissues and organs (Russel, 1973 and Yagodin, 1984), these results may be due to that $\mathrm{N}$ increase leaf chlorophyll content (Bartal et al., 2001). In the same tendency, Fleafel (2005), Balliu et al .,(2008) and Lima et al. (2014) reported that vegetative growth parameters of eggplant were increased with the increment of $\mathrm{N}$ application rate. With respect to the effect of organic mulch on vegetative growth parameters, the results in Table 3 indicated that all organic mulch treatments significantly increased plant height, number of leaves, number of brunches, plant fresh weight and leaf area per plant compared with bare soil treatment. Plants mulched with rice straw gave the best values compared with wheat straw or dry grass treatment in both seasons. The positive mulch effect may be due to keeping the soil moisture and temperature in favorable range for growth. These results are in agreement with the findings of Carter and Johnson (1988) on eggplant, Thakur et al. (2000) on pepper and Shaikh and Fouda (2008) on cucumber. The interaction effect of $\mathrm{N}$ rates and organic mulch treatments on the vegetative growth characteristics of eggplant were not significant in both seasons.

TABLE 3. Effect of nitrogen rates, organic mulch and their interaction on vegetative growth parameters of eggplants during late summer seasons of 2013 and 2014.

\begin{tabular}{|c|c|c|c|c|c|c|c|c|c|c|c|}
\hline \multicolumn{2}{|c|}{ Treatments } & \multicolumn{5}{|c|}{2013 Season } & \multicolumn{5}{|c|}{2014 season } \\
\hline 宽 & \multirow[t]{4}{*}{ 弟总 } & 离 总 & 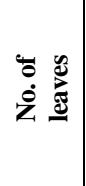 & 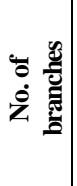 & 苛 & 式 泀 & 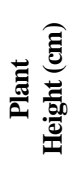 & 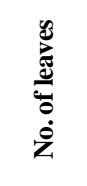 & 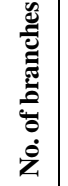 & 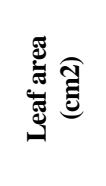 & 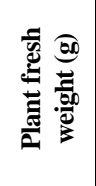 \\
\hline 50 & & $88.1 \mathrm{~b}$ & $171.6 \mathrm{~b}$ & $15.8 \mathrm{~b}$ & $6789.5 \mathrm{~b}$ & $854.3 \mathrm{~b}$ & $86.1 \mathrm{~b}$ & $166.6 \mathrm{~b}$ & $13.8 \mathrm{c}$ & $6599.7 \mathrm{~b}$ & $844.3 \mathrm{~b}$ \\
\hline 100 & & $96.4 \mathrm{ab}$ & $220 \mathrm{ab}$ & $26.5 \mathrm{a}$ & 10189.9ab & $1078.5 \mathrm{ab}$ & $93.4 \mathrm{~b}$ & $216.8 \mathrm{ab}$ & $23.5 \mathrm{~b}$ & $10010.9 \mathrm{ab}$ & $1063.5 \mathrm{ab}$ \\
\hline 150 & & $103.5 \mathrm{a}$ & $269.9 \mathrm{a}$ & $28.8 \mathrm{a}$ & $16184.2 \mathrm{a}$ & $1297.8 \mathrm{a}$ & $102.5 \mathrm{a}$ & $266.9 \mathrm{a}$ & $27.8 \mathrm{a}$ & $16002.1 \mathrm{a}$ & $1277.8 \mathrm{a}$ \\
\hline & Bare soil & $90.3 \mathrm{~b}$ & $181.8 \mathrm{~b}$ & $18.2 \mathrm{~b}$ & $7043.0 \mathrm{~b}$ & $808.5 b$ & $88.3 b$ & $177.8 \mathrm{~b}$ & $16.2 \mathrm{~b}$ & $6900.9 \mathrm{~b}$ & $793.5 b$ \\
\hline & Rice straw & $100.2 \mathrm{a}$ & $260.8 \mathrm{a}$ & $27.7 \mathrm{a}$ & $13292.5 \mathrm{a}$ & $1258.0 \mathrm{a}$ & $93.4 \mathrm{ab}$ & $256.8 \mathrm{a}$ & $25.7 \mathrm{a}$ & $13103.7 \mathrm{a}$ & $1243.5 \mathrm{a}$ \\
\hline & Wheat straw & $98.2 \mathrm{a}$ & $232.8 \mathrm{ab}$ & $23.7 \mathrm{a}$ & $11961.8 \mathrm{a}$ & $1070.0 \mathrm{a}$ & $96.2 \mathrm{a}$ & $228.8 \mathrm{ab}$ & $21.7 \mathrm{a}$ & $11770.0 \mathrm{a}$ & $1155.0 \mathrm{a}$ \\
\hline & Dry grass & $95.4 \mathrm{ab}$ & $207.5 \mathrm{ab}$ & $23.7 \mathrm{a}$ & $11920.7 \mathrm{a}$ & $1170.0 \mathrm{a}$ & $98.2 \mathrm{a}$ & $203.5 \mathrm{ab}$ & $23.2 \mathrm{a}$ & $11709.5 \mathrm{a}$ & $1055.4 \mathrm{a}$ \\
\hline \multirow{4}{*}{50} & Bare soil & 81.2 & 141.5 & 11.0 & 4515.7 & 653.5 & 79.2 & 136.5 & 9.0 & 4356.9 & 643.5 \\
\hline & Rice straw & 92.0 & 209.5 & 21.5 & 7949.6 & 1044.0 & 84.8 & 204.5 & 19.5 & 7774.4 & 903.0 \\
\hline & Wheat straw & 92.5 & 162.5 & 16.5 & 7169.9 & 806.7 & 90.0 & 168.0 & 12.0 & 6965.5 & 1034.0 \\
\hline & Dry grass & 86.8 & 173.0 & 14.0 & 7522.7 & 913.0 & 90.5 & 157.5 & \begin{tabular}{l|}
14.5 \\
\end{tabular} & 7302.0 & 796.7 \\
\hline \multirow{4}{*}{100} & Bare soil & 91.5 & 162.0 & \begin{tabular}{l|l}
19.0 \\
\end{tabular} & 5129.5 & 763.5 & 88.5 & 158.0 & \begin{tabular}{l|}
16.0 \\
\end{tabular} & 5003.0 & 748.5 \\
\hline & Rice straw & 97.5 & 271.5 & 31.5 & 13884.7 & 1294.5 & 94.5 & 244.0 & 28.5 & 13660.8 & 1279.5 \\
\hline & Wheat straw & 101.0 & 248.0 & 27.5 & 11979.8 & 1026.0 & 92.7 & 267.5 & 25.0 & 11808.6 & 1215.0 \\
\hline & Dry grass & 95.7 & 201.5 & 28.0 & 9765.7 & 1230.0 & 98.0 & 197.5 & 24.5 & 9571.4 & 1011.0 \\
\hline \multirow{4}{*}{150} & Bare soil & 98.2 & 242.0 & 24.5 & 11484.3 & 1008.5 & 97.2 & 239.0 & 23.5 & 11341.2 & 988.5 \\
\hline & Rice straw & 107.0 & 325.0 & 30.0 & 18043.3 & 1568.0 & 100.8 & 322.0 & 29.0 & 17876.0 & 1548.0 \\
\hline & Wheat straw & 107.0 & 258.5 & 31.5 & 16735.6 & 1378.5 & 106.0 & 251.0 & 28.0 & 16536.1 & 1296.0 \\
\hline & Dry grass & 101.8 & 254.0 & 29.0 & 18473.6 & 1236.0 & 106.0 & 255.5 & 30.5 & 18255.2 & 1358.5 \\
\hline
\end{tabular}

Values having the same alphabetical letter within each factors and those not having any alphabetical letters (in interaction effect) are not significantly different at the 5\% level, according to Duncan's multiple range test. 
Fruit yield

Data presented in Table 4 cleared that early and total fruit yields of eggplant were significantly increased by increasing $\mathrm{N}$ rate from 50 to $150 \mathrm{~kg} \mathrm{~N}$ per feddan. The highest early and total fruit yields were obtained from the application of $100 \mathrm{and} / \mathrm{or} 150 \mathrm{~kg} \mathrm{~N}$ per feddan, respectively with no significant effect between them in total yield while the lowest values were related to the lower nitrogen application (50 kg N/ fed.). The positive effect of nitrogen on yield might be due to its stimulating effect on the vegetative growth parameters (Table 3) which form the base for flowering and fruiting (Aminifard et al., 2010). Similar results have been reported by Pal et al. (2002), Devi et al. (2002) and Amiri et al. (2012).

TABLE 4. Effect of nitrogen rates, organic mulch and their interaction on both early and total yield and nitrogen use efficiency during late summer seasons of 2013 and 2014.

\begin{tabular}{|c|c|c|c|c|c|c|c|}
\hline \multicolumn{2}{|c|}{ Treatments } & \multicolumn{3}{|c|}{2013 Season } & \multicolumn{3}{|c|}{2014 season } \\
\hline $\begin{array}{c}\text { N Rate } \\
\text { (kg/fed.) }\end{array}$ & \multirow{4}{*}{$\begin{array}{l}\text { Organic } \\
\text { mulch }\end{array}$} & $\begin{array}{c}\text { Early } \\
\text { yield } \\
\text { (ton/fed.) }\end{array}$ & $\begin{array}{c}\text { Total yield } \\
\text { (ton/fed.) }\end{array}$ & NUE & $\begin{array}{c}\text { Early yield } \\
\text { (ton/fed.) }\end{array}$ & $\begin{array}{l}\text { Total yield } \\
\text { (ton/fed.) }\end{array}$ & NUE \\
\hline 50 & & $13.5 b$ & $47.2 \mathrm{~b}$ & $94.5 \mathrm{a}$ & $13.2 \mathrm{~b}$ & $46.7 b$ & $93.4 \mathrm{a}$ \\
\hline 100 & & $14.9 \mathrm{a}$ & $53.3 \mathrm{a}$ & $53.3 b$ & $14.2 \mathrm{a}$ & $51.1 \mathrm{a}$ & $51.1 \mathrm{~b}$ \\
\hline 150 & & $13.4 \mathrm{~b}$ & $54.7 \mathrm{a}$ & $36.5 c$ & $13.2 \mathrm{~b}$ & $52.0 \mathrm{a}$ & $34.69 \mathrm{c}$ \\
\hline & Bare soil & $14.5 \mathrm{a}$ & $46.7 b$ & $54.8 \mathrm{~b}$ & $14.3 \mathrm{a}$ & $46.6 c$ & $55.2 \mathrm{c}$ \\
\hline & Rice straw & $14.2 \mathrm{ab}$ & $54.5 \mathrm{a}$ & $65.0 \mathrm{a}$ & $13.2 \mathrm{~b}$ & $51.9 a$ & $62.5 \mathrm{a}$ \\
\hline & Wheat straw & $13.6 \mathrm{ab}$ & $52.4 a$ & $62.2 \mathrm{a}$ & $13.3 \mathrm{~b}$ & $50.1 \mathrm{~b}$ & $60.0 \mathrm{~b}$ \\
\hline & Dry grass & $13.5 b$ & $53.4 \mathrm{a}$ & $63.6 a$ & $13.3 b$ & $51.1 \mathrm{ab}$ & $61.1 \mathrm{ab}$ \\
\hline \multirow{4}{*}{50} & Bare soil & 13.9 & 41.3 & $82.6 \mathrm{~b}$ & $14.2 \mathrm{ab}$ & 42.3 & $84.6 \mathrm{c}$ \\
\hline & Rice straw & 13.7 & 50.5 & $101.1 \mathrm{a}$ & $12.6 \mathrm{e}$ & 49.6 & $99.1 \mathrm{a}$ \\
\hline & Wheat straw & 13.6 & 47.8 & $95.5 \mathrm{a}$ & $13.4 \mathrm{~cd}$ & 47.1 & $94.1 \mathrm{a}$ \\
\hline & Dry grass & 12.6 & 49.4 & $98.8 \mathrm{a}$ & $12.6 \mathrm{e}$ & 47.8 & $95.6 \mathrm{~b}$ \\
\hline \multirow{4}{*}{100} & Bare soil & 15.4 & 48.2 & $48.2 \mathrm{~d}$ & $14.6 \mathrm{a}$ & 48.1 & $48.1 \mathrm{e}$ \\
\hline & Rice straw & 15.11 & 55.8 & $55.8 \mathrm{c}$ & $14 \mathrm{abc}$ & 52.6 & $52.6 \mathrm{~d}$ \\
\hline & Wheat straw & 14.9 & 54.5 & $54.5 c$ & 13.9abc & 51.6 & $51.6 \mathrm{~d}$ \\
\hline & Dry grass & 14.2 & 54.7 & $54.7 \mathrm{c}$ & $14.2 \mathrm{ab}$ & 52.1 & $52.1 \mathrm{~d}$ \\
\hline \multirow{4}{*}{150} & Bare soil & 14.1 & 50.7 & $33.8 \mathrm{e}$ & $14.0 \mathrm{abc}$ & 49.3 & $32.9 \mathrm{~g}$ \\
\hline & Rice straw & 13.7 & $57.2 \mathrm{~d}$ & $38.2 \mathrm{e}$ & $13.1 \mathrm{de}$ & 53.7 & $35.8 \mathrm{f}$ \\
\hline & Wheat straw & 12.3 & 54.9 & $36.6 \mathrm{e}$ & $13.6 \mathrm{bcd}$ & 51.6 & $34.4 \mathrm{fg}$ \\
\hline & Dry grass & 13.5 & 55.9 & $37.3 \mathrm{e}$ & $13.1 \mathrm{de}$ & 53.5 & $35.7 \mathrm{f}$ \\
\hline
\end{tabular}

Values having the same alphabetical letter within each factors and those not having any alphabetical letters (in interaction effect) are not significantly different at the 5\% level, according to Duncan's multiple range test.

On the other hand, Nitrogen use efficiency (NUE) had a negative correlation with the increase of $\mathrm{N}$ application rate. Therefore, the highest records were obtained from $50 \mathrm{~kg} \mathrm{~N}$ per feddan while $150 \mathrm{~kg}$ had the lowest ones in both seasons. In this concern, Halitligil \& Kislal (2002) and Kostadinov \& Kostadinova (2014) cleared that there was a negative relation between fresh fruit yield and nitrogen use efficiency.

Egypt. J. Hort. Vol. 42, No. 2 (2015) 
Concerning the effect of organic mulch treatments on fruit yield, results of mean comparisons in Table 4 showed that the highest early yield was obtained from bare soil compared with organic mulch treatments (Rice straw, wheat straw and dry grass) which had the highest values of total yield and NUE in both seasons. The plants mulched with rice straw had the best results followed by dry grass and wheat straw mulch, respectively compared with bare soil treatment in both seasons.

These results might be due to the fact that, when soil is covered with organic mulch, this led to the moderation of soil temperature (Table 2), reduction of nutrient loss by leaching, conservation of water and weeds management. Similar results were obtained by Thakur et al. $(2000,2002)$ and Law et al. (2006) on bell pepper, Moreno et al. (2009) on tomato and Pirbonch et al. (2012) on eggplant. They found that organic mulch increased fruit yield compared to bare soil treatment. Concerning the interaction effect between nitrogen fertilizer rate and organic mulch treatments on fruit yield of eggplant, no significant differences were observed (Table 4) in both seasons, except for the early yield in the second one, as the interaction was significant. The bare soil treatment with the application of $100 \mathrm{~kg} \mathrm{~N}$ per feddan had the highest early fruit yield followed by bare soil and dry grass with application 50 and $100 \mathrm{~kg} \mathrm{~N}$ per feddan, respectively with no significant differences between both treatments.

Concerning NUE, the effect of combined interaction between $\mathrm{N}$ application rate and organic mulch treatments in Table 4 exhibited a significant difference in both seasons. The highest records was obtained from plants fertilized with $50 \mathrm{~kg}$ $\mathrm{N}$ per feddan and mulched with rice straw. In contrast, bare soil plants fertilized with $150 \mathrm{~kg} \mathrm{~N}$ resulted in the lowest NUE value in both seasons.

\section{Fruit quality}

Data in Table 5 revealed that the average fruit weight, fruit length and fruit width were significantly affected by nitrogen application rates in both seasons. The data cleared that the highest values of average fruit weight and fruit length and width were recorded from application of 150 followed by $100 \mathrm{~kg} \mathrm{~N}$ per feddan compared with $50 \mathrm{~kg} \mathrm{~N}$ which had the lowest ones in both seasons. Similar results were obtained by Aujla et al. (2007) and Amiri et al. (2012), they found that increasing the rate of $\mathrm{N}$ application increased fruit length and width. Concerning the organic mulch, data in Table 5 cleared that there were significant differences among treatments on average fruit weight and fruit length and width in both seasons. The highest values of abovementioned parameters were obtained from plants mulched with rice straw followed by wheat straw or dry grass compared with bare soil treatment which had the lowest one in both seasons. The positive effects of organic mulch are confirmed by these of Roberts and Anderson (1994) using wheat straw mulch on pepper, Palada and Davis (2000) using grass straw mulch on pepper, Rodriguez (2007) using rice bran mulch on tomato and Pirbonch et al. (2012) on eggplant. 
TABLE 5. Effect of nitrogen rates, organic mulch and their interaction on average fruit weight, fruit length and fruit width of eggplants during late summer seasons of 2013 and 2014.

\begin{tabular}{|c|c|c|c|c|c|c|c|}
\hline \multicolumn{2}{|c|}{ Treatments } & \multicolumn{3}{|c|}{2013 Season } & \multicolumn{3}{|c|}{2014 season } \\
\hline $\begin{array}{l}\text { N Rate } \\
\text { (kg/fed.) }\end{array}$ & $\begin{array}{c}\text { Organic } \\
\text { mulch }\end{array}$ & $\begin{array}{c}\text { Av. Fruit } \\
\text { Weight } \\
\text { (g) }\end{array}$ & $\begin{array}{c}\text { Fruit } \\
\text { Length } \\
\text { (cm) }\end{array}$ & $\begin{array}{c}\text { Fruit } \\
\text { Width } \\
\text { (cm) }\end{array}$ & $\begin{array}{c}\text { Av. Fruit } \\
\text { Weight } \\
\text { (g) }\end{array}$ & $\begin{array}{c}\text { Fruit } \\
\text { Length } \\
\text { (cm) }\end{array}$ & $\begin{array}{c}\text { Fruit } \\
\text { Width } \\
\text { (cm) }\end{array}$ \\
\hline 50 & & $335 b$ & $11.4 \mathrm{~b}$ & $11.0 \mathrm{~b}$ & $320.0 \mathrm{~b}$ & $9.4 \mathrm{~b}$ & $10.0 \mathrm{ab}$ \\
\hline 100 & & $396.4 \mathrm{ab}$ & $12.5 \mathrm{ab}$ & $11.4 \mathrm{ab}$ & $386.6 \mathrm{ab}$ & $10.4 \mathrm{~b}$ & $9.5 \mathrm{~b}$ \\
\hline 150 & & $489.3 \mathrm{a}$ & $13.1 \mathrm{a}$ & $12.0 \mathrm{a}$ & $481.3 \mathrm{a}$ & $12.1 \mathrm{a}$ & $10.8 \mathrm{a}$ \\
\hline & Bare soil & $378.3 \mathrm{c}$ & $11.7 \mathrm{~b}$ & $10.7 b$ & $367.3 \mathrm{c}$ & $9.9 \mathrm{c}$ & $9.1 \mathrm{~b}$ \\
\hline & Rice straw & $441.1 \mathrm{a}$ & $13.0 \mathrm{a}$ & $11.8 \mathrm{a}$ & $430.1 \mathrm{a}$ & $11.1 \mathrm{ab}$ & $10.5 \mathrm{a}$ \\
\hline & Wheat straw & $421.3 \mathrm{ab}$ & $12.8 \mathrm{a}$ & $11.7 \mathrm{a}$ & $410.3 \mathrm{ab}$ & $11.3 \mathrm{a}$ & $10.4 \mathrm{a}$ \\
\hline & Dry grass & $387.2 \mathrm{bc}$ & $11.8 \mathrm{~b}$ & $11.8 \mathrm{a}$ & $376.2 b c$ & $10.1 b c$ & $10.4 \mathrm{a}$ \\
\hline \multirow{4}{*}{50} & Bare soil & $287.0 \mathrm{f}$ & 10.3 & 10.0 & $272.0 \mathrm{f}$ & 8.3 & 9.0 \\
\hline & Rice straw & $353.5 \mathrm{e}$ & 12.3 & 11.2 & $338.5 \mathrm{e}$ & 10.3 & 10.2 \\
\hline & Wheat straw & $361.0 \mathrm{de}$ & 12.3 & 11.5 & $346.0 \mathrm{e}$ & 10.3 & 10.5 \\
\hline & Dry grass & $338.5 \mathrm{e}$ & 10.8 & 11.3 & $323.5 \mathrm{e}$ & 8.8 & 10.3 \\
\hline \multirow{4}{*}{100} & Bare soil & $371.3 \mathrm{de}$ & 11.8 & 11.0 & $361.3 \mathrm{de}$ & 9.4 & 8.9 \\
\hline & Rice straw & $436.8 \mathrm{bc}$ & 13.8 & 11.6 & $426.8 \mathrm{bc}$ & 11.1 & 9.6 \\
\hline & \begin{tabular}{|l|} 
Wheat straw \\
\end{tabular} & $369.3 \mathrm{de}$ & 12.3 & 11.5 & $359.3 \mathrm{de}$ & 10.8 & 9.5 \\
\hline & Dry grass & $409.3 \mathrm{~cd}$ & 12.0 & 11.9 & $399.3 \mathrm{~cd}$ & 10.1 & 9.9 \\
\hline \multirow{4}{*}{150} & Bare soil & $476.8 \mathrm{~b}$ & 13.0 & 11.1 & $468.8 \mathrm{~b}$ & 12.0 & 9.4 \\
\hline & Rice straw & $533.0 \mathrm{a}$ & 12.9 & 12.7 & $525.0 \mathrm{a}$ & 11.9 & 11.7 \\
\hline & Wheat straw & $533.5 \mathrm{a}$ & 14.0 & 12.2 & $525.5 \mathrm{a}$ & 13.0 & 11.2 \\
\hline & Dry grass & $413.8 \mathrm{~cd}$ & 12.5 & 12.1 & $405.8 \mathrm{~cd}$ & 11.5 & 11.1 \\
\hline
\end{tabular}

Values having the same alphabetical letter within each factors and those not having any alphabetical letters (in interaction effect) are not significantly different at the 5\% level, according to Duncan's multiple range test

The combined interaction between $\mathrm{N}$ application rates and organic mulch treatments had no significant effects on fruit length and width and significant effect on average fruit weight in both seasons. The highest value of average fruit weight was obtained from plants fertilized with $150 \mathrm{~kg} \mathrm{~N}$ per feddan and mulched with rice or wheat straw. On the opposite, the lowest one was recorded from the combined interaction between $50 \mathrm{~kg} \mathrm{~N}$ per feddan and bare soil treatment. These results are in harmony with those obtained by Aminifard et al. (2010) who reported that there was a positive correlation between average fruit weight and $\mathrm{N}$ application rate per feddan.

\section{References}

Abdul-Baki, A.A. and Stommel, J.R. (1996) Hairy vetch mulch Favorably impacts yield of processing tomatoes. HortScience, 31 (3), 338 - 340.

Aman, S. and Rab, A. (2013) Response of tomato to nitrogen levels with or without humic acid. Sarhad J. Agric., 29 (2), 181- 186.

Aminifard, M.H., Aroiee, H., Fatemi, H., Ameri, A. and Karimpour, S. (2010) Responses eggplant (Solanum melongena L .) to different rates of nitrogen under field conditions. J. Central European Agric., 11 (4), 453 - 458.

Egypt. J. Hort. Vol. 42, No. 2 (2015) 
Amiri, E., Gohari, A.A. and Esmailian, Y. (2012) Effect of irrigation and nitrogen on yield, yield component and water use efficiency of eggplant. Afr. J. Biotechnology, 11 (13), 3070 - 3079.

Aujla, M.S, Thind, H.S. and Butter, G.S. (2007) Fruit yield and water efficiency of eggplant (Solanum melongena L.) as influenced by different quantites of nitrogen and water applied through drip and furrow iorrigation. J. Sci. Hort., 112, 142 - 148.

Azarpour, E.A., Motamed, M.K., Moraditochaee, M. and Bozorgi, H.R. (2012) Effects of bio, mineral nitrogen fertilizer management under humic acid foliar spraying on fruit yield and several traits of eggplant (Solanum melongena L.). Afr. J. Agric. Res., 7, 1104 - 1109.

Balliu, A., Sallaku, G. and Kuci, S. (2008) Nitrogen concentration in nutrient solution and module volume effects on the growth characters and yield potentials of eggplant. J. Acta Hort., 801, 1373- 1377.

Bartal, A., Aloni, B., Karim, L. and Rosenberg, R. (2001) Nitrogen nutrient of greenhouse pepper: Effects of nitrogen concentration and NO3:NH4 ratio on growth, transpiration and nutrient uptake. J. Hort. Sci., 36, 1525- 1529.

Black, C.A. (1965) "Methods of Soil Analysis". Amer. Soc. Agron. Inc. Madison, Wisconsin, USA.

Bozorgi, H.R. (2012) Study effects of nitrogen fertilizer management under nano iron chelate foliar spraying on yield and yield component of eggplant (Solanum melongena L.). Aren J. Agric. And Biological Sci., 7 (4), 223 - 237.

Carter, J. and Johnson, C. (1988) Influence of different types of mulches on eggplant production. HortScience, 23 (1), 143 - 145.

Devi, H.H., Maity, T.K., Paria, N.C. and Thapa, U. (2002) Response of brinjal to different sources of nitrogen. J. Vet. Sci., 29 (1), 45 - 47.

El-Aidy, F., El-Sawy, B.I., Hindy, F. and Omran, S. (2000) Effect of rice hulls mulch on cucumber production under plastic greenhouse during late summer season. Proc. The $6^{\text {th }}$ Arab Inter. Conf. on Materials Sci.(Plastic Material for Agriculture Applications ), 19-22 November, Alex. Egypt, pp. 229 - 239.

El-Nemr, M.A., El-Desuki, M., Fawzy, Z.F. and El-Bassiony, A.M. (2012) Yield and fruit quality of eggplant as affected by NPK sources and micronutrient application. $J$. Appl. Sci. Res., 8, 1351 - 1357.

El-Sawy, B.I. (1993) Influence of some mulches on tomato crops (Lycopersicon esculentum Mill.). I. Vegetative growth, flowering and fruit setting characteristics, soil temperature and moisture. J. Agric. Res. Tanta Univ., 19 (3), 655 - 672.

Feleafel, M.N. (2005) Response of growth, yield and quality of eggplant to varying nitrogen rates and their application systems. J. Agric. \& Env. Sci. Alex. Univ., 4 (1), $122-136$. 
Feleafel, M.N. and Mirdad, Z.M. (2013) Optimizing the nitrogen, phosphorus and potash fertigation rates and frequency for eggplant in arid region. Int. J . Agric Biol., 15, $737-742$.

Halitligil, M.B., Akin, A.I. and Kislal, H. (2002) Yield, nitrogen uptake and nitrogen use efficiency by nitrogen rates applied with dirp- irrigation under greenhouse conditions. Int. At Agency Tech. Doc., 126, 99 - 110.

Jackson, J. and Strelec, V. (1967) "Soil Chemical Analysis". Prentice Hall of India , Private Limited, New Delhi, 115 p.

Kostadinov, K. and Kostadinova, S. (2014) Nitrogen efficiency in eggplant (Solanum melongena L.) depending on fertilizing. Bulgarian J. Agric. Sci., 20 (2), 287 - 292.

Law, D.M., Rowell, A.B. Snyder, J.C. and Williams, M.A. (2006) Weed control efficacy of organic mulches in two organically managed bell pepper production systems. Hort. Tech., 16 (2), 225-232.

Lima, P.R., Carlesso, R.E., Borsoi, A., Ecco, M., Fernandes, F.V., Mezzalira, E.J., Rawpim, L., Rosset, J.S., Battistus, A.G., Malavasi, V.C. and Da Fonseca, P.R. (2014) Effects of different rates of nitrogen $(\mathrm{N})$ and phosphorus pentoxide (P2O5) on eggplant yield . Afr. J. Agric. Res., 9 (19), 1435-1441.

Little, T.A. and Hills, F.J. (1972) "Statistical Methods in Agriculture Research", California Univ. Davis, 242 p.

Moraditochaee, M., Bozorgi, H.R. and Halajisani, N. (2011) Effect of Vermicompost application and nitrogen fertilizer rates on fruit yield and several attributes of eggplant (Solanum melongena L.) in Iran. World Appl. Sci. J., 15 (12), 174 - 178.

Moreno, M.M., Moreno, A. and Mancebco, I. (2009) Comparison of different mulch materials in a tomato (Solanum lycopersicum L.) crop. Spanish J. Agric. Res., 7 (2), $454-464$.

Najafva, D.S., Alemzadeh, N.A. and Sedighie, F.D. (2008) Effect of different levels of nitrogen fertilizer with two types of bio- fertilizers on growth and yield of two cultivars of tomato (Lycopersicon sculentum Mill). Asian J. plant Sci.,7 (8), pp. 757-761.

Pal, S., Saimbhi, M.S. and Bal, S.S. (2002) Effect of nitrogen and phosphorus levels on growth and yield of brinjal hybrid (Solanum melongena L.). J. Vet. Sci., 29, 90 - 91.

Palada, C. and Davis, A.M. (2000) Comparison of organic and synthetic mulch for bell pepper production at three levels of drip irrigation. Proc. Fl. State Hort. Soc., 113, $234-236$.

Pessarakli, M.M. and Dris, R. (2004) Influence of fertigation, mulches and $\mathrm{CO} 2$ enrichment on eggplant production. Food, Agriculture \& Environment, 2 (1), 220 -223.

Pirbonch, H., Ghasemi, M., Gohari, A.A., Bahari, B. and Bazkiyaei, Z.B. (2012) Effect of Irrigation and straw mulch on yield and yield components of eggplant (Solanum melongena L.). Inter. J. Applied Basic Sci., 3 (1), 46 - 51.

Egypt. J. Hort. Vol. 42, No. 2 (2015) 
Roberts, B.W. and Anderson, J.A. (1994) Canopy shade and soil mulch affect yield and solar injury of bell pepper. Hort. Sci., 29 (4), 258 - 260.

Rodriguez, G.R. (2007) Effect of rice bran mulching on growth and yield of cherry tomato. Cien. Inv. Agr., 34 (3), 181-186.

Russel, E.W. (1973) "Soil Conditions and Plant Growth", 10" ed. London. E.L.B.S.P.

Saeed, R. and Ahmad, R. (2009) Vegetative growth and yield of tomato as affected by the application of organic mulch and gypsum under saline rhizosphere. Pak. J. Bot. 41 (6), 3093-3105

Sathappan, C.T., Arivukarasu, K., Rameshkumar, S., Murugon, G. and Kathiresan, R.M. (2012) Sustainable management of weeds in rainfed eggplant in india. Pak. $J$. weed Sci. Res., 18, $557-564$.

Shaikh, A. and Fouda, T. (2008) Effect of different mulching types on soil temperature and cucumber production under Libyan conditions. Misr J. Eng., 25 (1), 160 -175.

Thakur, P.S., Thakur, A. and Kanavjia, S.P. (2000) Reversal of water stress effects. I. Mulching impact on the performance of Capsicum annuum under water deficit. Indian J. Hort., 57 (3), 250 - 254.

Thakur, P.S., Thakur, A. and Kanavjia, S.P. (2002) Reversal of water stress effects. II. Influence of growth regulator, mulching and potassium on the field performance of Capsicum anпиит L. under water stress . Indian J . Hort., 59 (4), 416 - 422.

Yagodin, B.A. (1984) "Agricultural Chemistry", $1^{\text {st }}$ ed., Mir publishers. Moscow.

(Received 22/ 6/ 2015; accepted 25/10/ 2015) 


$$
\begin{aligned}
& \text { اسـتجابة نمـو ومحصــول الباذنجـان للتغطيـة العضــوية والتســيد } \\
& \text { الازوتى بالعروة الصيفية المتأخرة }
\end{aligned}
$$

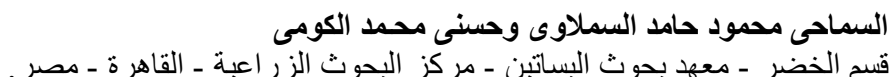

أجريت هذه الدر اسة في مزر عة خاصة بقرية الشمارقة ـ محافظة كفر الثيخ خلال

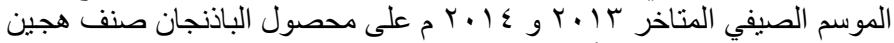

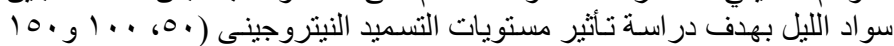

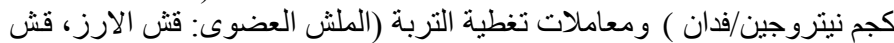

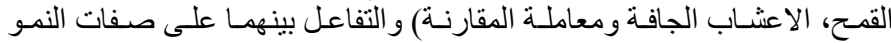
الخضري و المحصول وصفات الجودة لثمار الباذنجان.

ويمكن تلخيص اهم النتائج المتحصل عليها كالآتي:

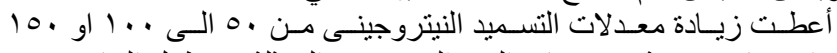

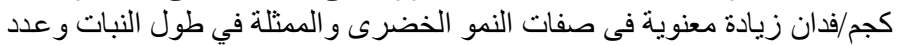

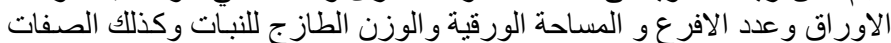

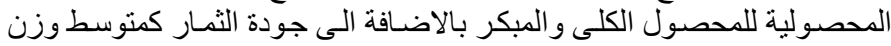

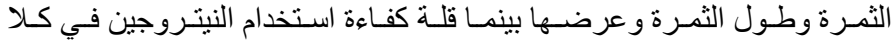

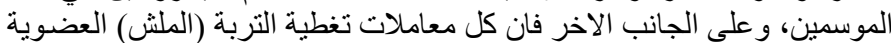

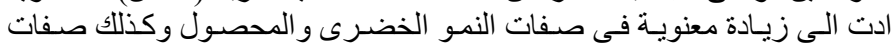
الجودة للثمار مقارنة بمعاملة المقارنة و التى أعطت أقل النتائج فى كلا الموسمين.

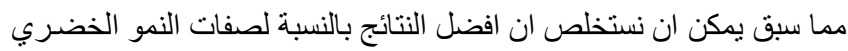

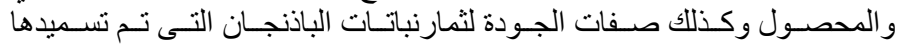

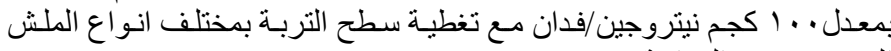
العضوى تحت الدر اسة. 